\title{
Review of the cedar and oak forest-associated Epuraea latipes species group (Coleoptera: Nitidulidae, Epuraeinae), with description of a new species from southern Turkey
}

\author{
Sakine Serap Avgın, Donatella Magri, Gloria Antonini, Emiliano Mancini, Nicklas Jansson, \\ Andrzej Lasoń, Andrew R. Cline \& Paolo Audisio*
}

Avgın, S. S., Magri, D., Antonini, G., Mancini, E., Jansson, N., Lasoń, A., Cline, A. R. \& Audisio, P. 2012: Review of the cedar and oak forest-associated Epuraea latipes species group (Coleoptera: Nitidulidae, Epuraeinae), with description of a new species from southern Turkey. — Entomol. Fenn. 23: 49-62.

A new species of Epuraea, Epuraea sutcuimamun Avgın, Lasoń \& Audisio sp. n., from southern Turkey (Taurus Chain) was identified using morphological analyses. This species is a member of a circum-Mediterranean endemic group of sap beetles, the Epuraea latipes species group of the Dadopora lineage, which are mostly associated with cedar (Cedrus spp.) forests. Herein, the new species is described, the previously unknown association of the little-known Epuraea subparallela Grouvelle 1896 with meso-xerophilous oaks is reported, and some new records from southern Turkey (Taurus Chain) are listed for the latter species (previously only known from the Nur Mts. in SE Turkey, Osmaniye and Iskenderun provinces). An identification key to species of Dadopora lineage is also provided. Finally, the main palaeogeographic events affecting the Miocene to Holocene dispersal and evolution of species/populations of the Dadopora lineage on cedars and oaks, and the coincident distributional dynamics of Western Palaearctic Cedrus populations throughout the Mediterranean Basin, are discussed.

S.S. Avgin, Kahramanmaras Sutcu Imam University, Faculty of Education, and Faculty of Arts and Science, Department of Biology, TR-46100 Kahrmanmaras, Turkey;E-mail: ssavgin@ksu.edu.tr; serapavgin@hotmail.com

D. Magri, Dipartimento di Biologia Ambientale, Sapienza Università di Roma, Piazzale Aldo Moro 5, I-00185, Rome, Italy; E-mail: donatella.magri@ uniromal.it

G. Antonini, Dipartimento di Biologia e Biotecnologie "Charles Darwin", Sapienza Università di Roma, Via Borelli 50, I-00161 Rome, Italy; E-mail: gloria.antonini@uniroma1.it

E. Mancini, Dipartimento di Scienze di Sanità Pubblica e Malattie Infettive, Sapienza Università di Roma, Piazzale Aldo Moro 5, I-00185, Rome, Italy; Email: emiliano.mancini@uniroma1.it

N. Jansson, Division of Ecology, Linköping University, 58183 Linköping, Sweden; E-mail:nicja@ifm.liu.se

A. Lasoń, ul. Wiejska 4B/85, 15-352 Biatystok, Poland; E-mail: haptos (a)interia.pl 


\begin{abstract}
A. R. Cline, Plant Pest Diagnostics Center, California Department of Food \& Agriculture, 3294 Meadowview Road, Sacramento, CA 95832-1448, USA; Email: acline@cdfa.ca.gov

P. Audisio (*corresponding author), Dipartimento di Biologia e Biotecnologie "Charles Darwin", Sapienza Università di Roma, Via Borelli 50, I-00161 Rome, Italy; E-mail: paolo.audisio@uniromal.it
\end{abstract}

Received 30 June 2011, accepted 15 November 2011

\section{Introduction}

Epuraea Erichson 1843 comprises more than 300 species worldwide (Grouvelle 1913, Reitter 1919, Sjöberg 1939, Audisio 1993, Kirejtshuk 1998, Jelínek \& Audisio 2007), and is the most specious genus within Nitidulidae. Within this likely paraphyletic genus, different authors have recognized several monophyletic derived species-groups and/or subgenera, or described closely related genera whose taxonomy needs to be disentangled (see Kirejtshuk 1998). A preliminary re-examination of the genus-level taxonomy of the subfamily Epuraeinae, based on morphological and molecular data, is in preparation ( $\mathrm{Au}-$ disio, unpublished data). The subgenus Dadopora Thomson, 1859 (type species: Nitidula guttata Olivier, 1811) has been recognized as a distinct taxon by Kirejtshuk (1998), but, pending for new phylogenetic analyses, more recently it was tentatively considered a synonym of Epuraea s. str. by Jelínek and Audisio (2007). Following further analyses, this subgenus represents a likely distinct and monophyletic lineage formally including only two closely related species distributed in the Western Palaearctic [i.e. E. guttata (Olivier, 1811) and E. fuscicollis (Stephens, 1832)], both widespread in Europe and the Near East.

However, this lineage certainly also contains the related E. latipes Grouvelle, 1896 clade (Audisio 1983, 1993). Both groups are characterized (Figs. 1-2) by many shared characters, including peculiarly wide, robust and triangular protibiae (especially males); robust and markedly convex (in transverse section) mesotibiae; mesotibiae 2.8-3.3 times as long as wide; absent or markedly reduced sexual dimorphism in male mesotibiae; characteristically wide male protarsal plates; lateral edges of pronotum and elytra fringed by a single dense series of relatively short but markedly distinct and non-recumbent golden setae; simple (never toothed) tarsal claws; a transverse rather than convex body shape; very narrowly flattened sides of pronotum and elytra; regularly and shallowly arcuately emarginated anterior edge of pronotum; weakly impressed and posteriorly slightly delimited antennal grooves on ventral side of head; space between mesocoxal cavities narrower than space between procoxal cavities; relatively short antennae; and metaventrite with a broadly $\mathrm{V}$-shaped posterior edge. All known species are mycetophagous sap-feeders (typically as larvae and adults), and are associated with old-growth oak or cedar forests in mostly xerophilous or mesoxerophilous vegetation zones.

The Epuraea latipes Grouvelle, 1896 species group of the Dadopora lineage, previously treated by Audisio (1983, 1993), comprises three species, in addition to the new species described below, that were believed to be all associated with cedar forests: E. latipes (northern Morocco and Algeria), E. rifensis Audisio, 1983 (northern Algeria and Morocco, with relictual populations in southern Spain), and E. subparallela Grouvelle, 1896 (Nur Mts. in SE Turkey) (see discussion below).

The recent discovery of a fourth species of this clade in SW Turkey, which appears closely related to $E$. latipes from western North Africa and was tentatively attributed to the true $E$. latipes by Lason (2007), and the rediscovery of $E$. subparallela Grouvelle, 1896 in southern Turkey caused us to reconsider the entire Dadopora lineage. The goal of this paper is to describe the new species, compare it with known members of the Epuraea latipes species-group, and construct a feasible scenario for the evolution of the Dadopora clade in the context of the known palae- 
geographic, palaeoecological, and molecular data of the distribution and evolution of Cedrus (Pinaceae) throughout the Mediterranean Basin.

\section{Material and methods}

Part of the studied material from southern Turkey (Taurus Chain) was collected by the first author using vinegar-baited pitfall traps during a series of entomological studies on the saproxylic insect fauna (see Waage 1985, Niemelä 1998, Lemieux \& Lindgren 1999, Koivula et al. 2003, and Brandmayr et al. 2005 for details of this trapping method). The fieldwork in an old-growth cedar forest (Cedrus libani A. Rich), in the proximity of Erdemli (Mersin province), was completed in the summer of 2010 by the first author. Pitfall traps were placed near and around trees, or in tree holes in cedar forests, and checked weekly during 20.VII.-13.VIII.2010. The material collected from the pitfall traps was immediately sorted and preserved in $80 \%$ ethanol and retained for morphological analyses (CAK, CAR, NMPC, ARCC and CLB, see below for definitions of acronyms). Some specimens were preserved in pure acetone for molecular analyses (CAR). Important additional material was also collected by N. J. together with Turkish colleagues, using window traps ( $30 \times 50 \mathrm{~cm}$ sitting on the tree trunk) in southern Turkey (Mersin and Isparta provinces), during a research on saproxylic beetle communities associated with oaks (Quercus spp.; Jansson \& Coskun 2008). This material is now preserved in CAR, EMDI, and CJL.

Museum specimens coincide mostly with those analyzed by Audisio (1983), and are found in CAR, NMPC, MNHN, BMNH, and CLB. Other material sources for the new species include specimens collected by R. Dobosz and R. Królik in S. Turkey [specimens from 20.VII. 2004 and 9.-12.VI.2000 at light, others by swiping method] during entomological expeditions to Anatolia (years 2000-2006) by the Upper Silesian Museum (Bytom) and associated Polish entomologists.

The digital image of the dorsal habitus of the holotype (Fig. 1) of Epuraea sutcuimamun Avgın, Lasoń \& Audisio, sp. n., was taken using a Nikon DS-L1 camera mounted on a Leika

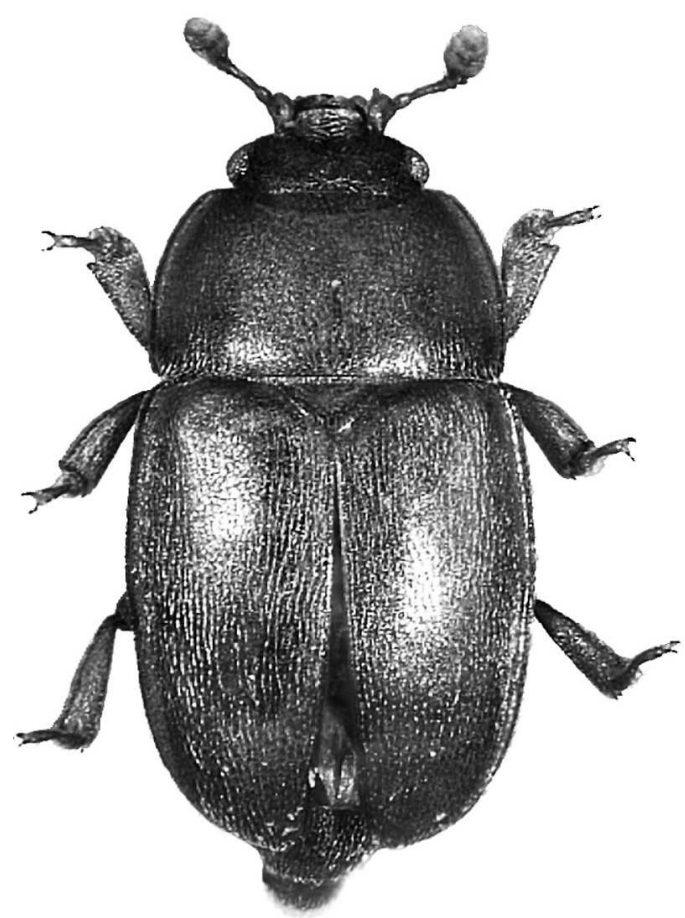

Fig. 1. Epuraea sutcuimamun sp. n., male holotype from Turkey, Mersin province, near Aydinlar village, CAK. Length $2.4 \mathrm{~mm}$. Scale bar $=1.0 \mathrm{~mm}$.

MZ12.5 stereoscopic microscope and processed by Auto-Montage Pro, version 5.03.0096.

Acronyms of insect collections are:

- BMNH: The Natural History Museum, London, UK

- CAR: P. Audisio's collection, Dipartimento di Biologia e Biotecnologie "C. Darwin", Sapienza Università di Roma, Italy

- ARCC: A. R. Cline's collection, currently housed at the Plant Pest Diagnostics Center in Sacramento, California

- CAK: S. S. Avgın's collection, Department of Biology, Kahramanmaras Sutcu Imam University, Turkey

- CLB: A. Lasoń's private collection, $\mathrm{Bia}^{3} \mathrm{ystok}$, Poland

- CJL: Nicklas Jansson's private collection, Linköping, Sweden

- EMDI: Entomological Museum at Forest Faculty, Suleyman Demirel University in Isparta, Turkey 

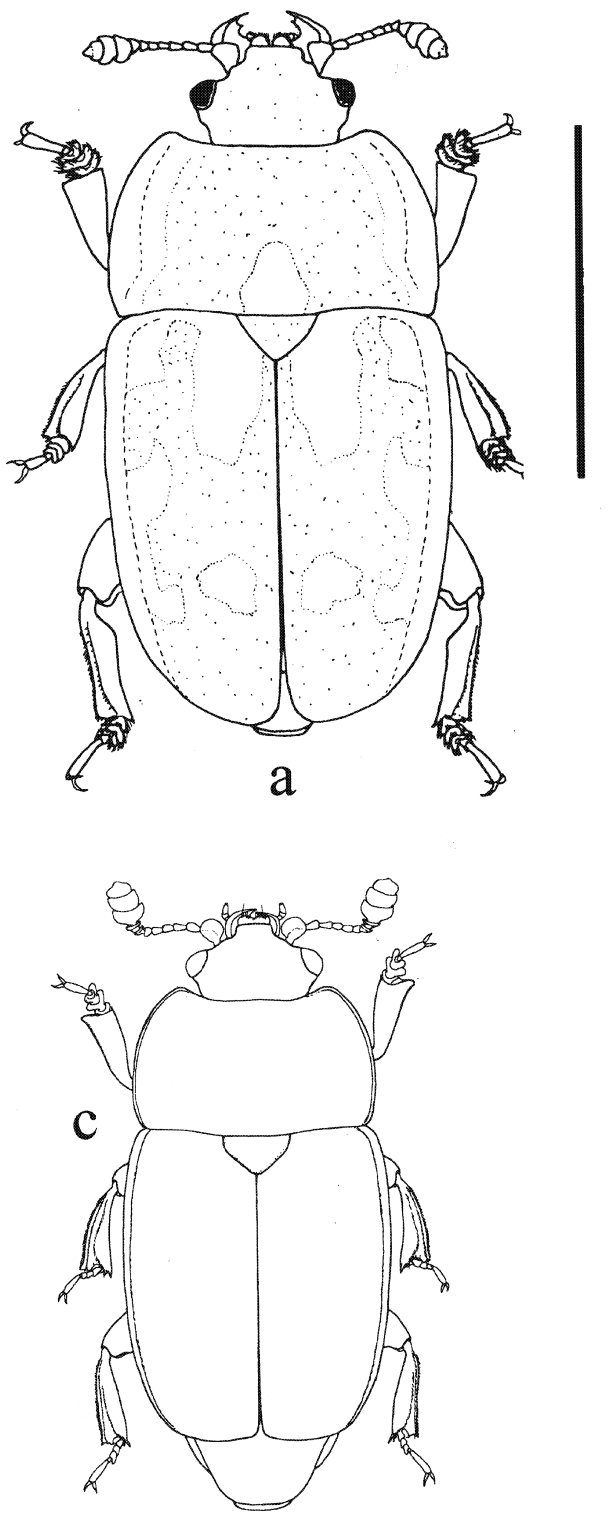

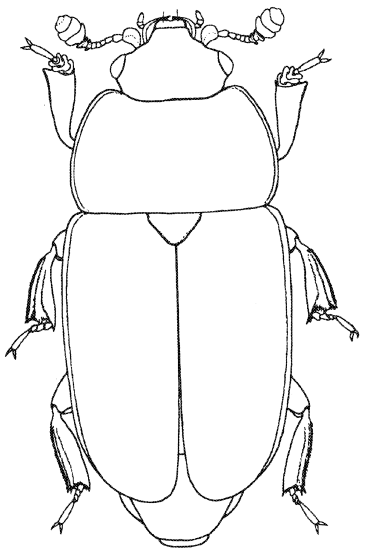

b

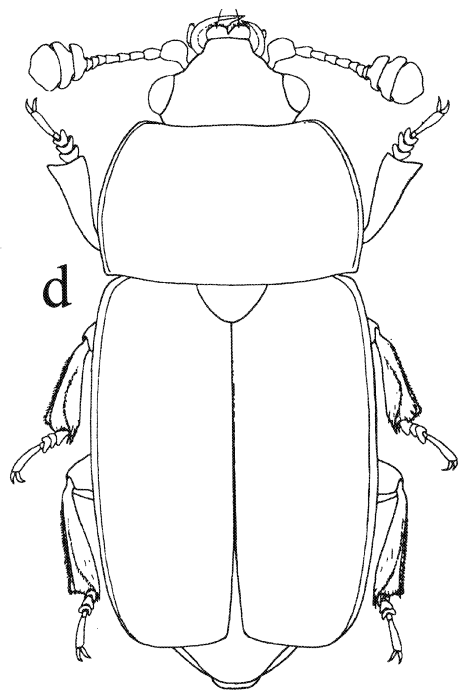

Fig. 2. - a. Male habitus outline of Epuraea guttata from Italy, Tuscany, Florence. - b. Male habitus outline of Epuraea latipes from Morocco, Rif, BabBesen, CAR. - c. Male habitus outline of Epuraea rifensis from Morocco, Rif, BabBesen, CAR. - d. Male habitus outline of Epuraea subparallela, male holotype from Turkey, Nur Mts. (above Akbez; = "Syria, Akbès", in the original label), MNHN. Scale bar $=2.0 \mathrm{~mm}$.

- MNHN: Muséum National d'Histoire Naturelle, Paris, France

3. Epuraea sutcuimamun Avgin,

- NMPC: National Museum (Natural History), Prague, Czech Republic

- NMW: Naturhistorisches Museum Wien, Austria

- RKK: Roman Królik's private collection (Kluczbork, Poland)

- USMB: Upper Silesian Museum, Bytom, Poland

\section{Lasoń \& Audisio, sp. n. (Figs. 1; 3d-f)}

Type material. Holotype $\widehat{\partial}$ (CAK): Turkey, Mersin province, road Erdemli to Güzeloluk, nearly $30 \mathrm{~km}$ NE of Erdemli, Kargagedigi, near Aydinlar village, $1,350 \mathrm{~m}$ a.s.1., $36^{\circ} 44^{\prime} 51^{\prime} \mathrm{N}$, $34^{\circ} 07^{\prime} 51^{\prime \prime} \mathrm{E}$, vinegar-baited pitfall traps in ancient cedar forest, 20.-29.VII.2010, S. S. Avgin leg. (CAK).

Paratypes: same data as holotype, vinegarbaited pitfall traps in ancient cedar forest, 

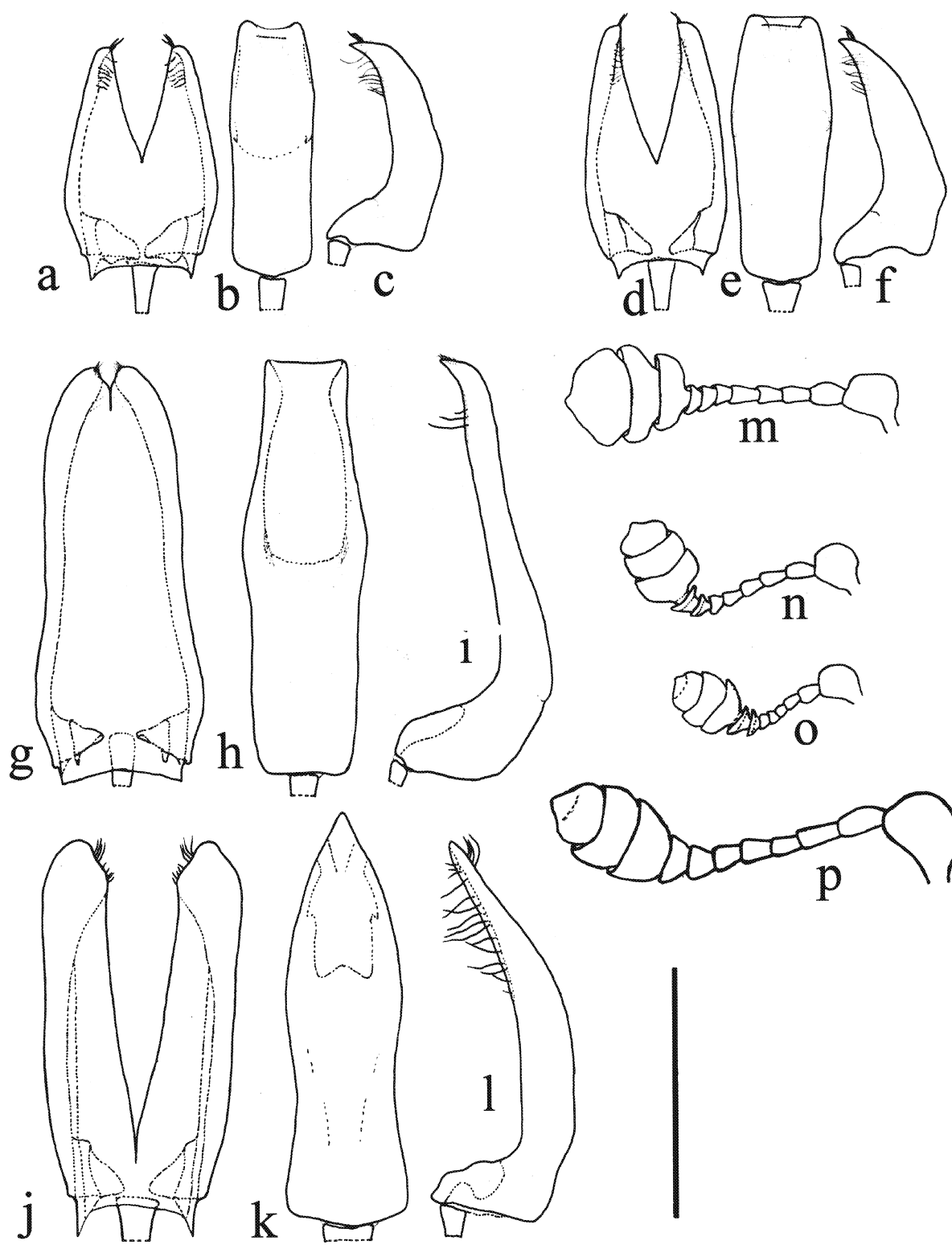

$\mathrm{p}$

Fig. 3. - a. Paramera, dorsal view, Epuraea latipes, male from Morocco, Rif, Bab-Besen, CAR. - b. Median lobe of aedeagus, dorsal view (same). - c. Paramera, lateral view (same). - d. Paramera, dorsal view, Epuraea sutcuimamun sp. $\mathbf{n}$., male holotype from Turkey, Mersin province, near Aydinlar village, CAK. - e. Median lobe of aedeagus, dorsal view (same). - f. Paramera, lateral view (same). - g. Paramera, dorsal view, Epuraea rifensis, male paratype from Morocco, Rif, Bab-Besen, CAR. - h. Median lobe of aedeagus, dorsal view (same). - i. Paramera, lateral view (same). - j. Paramera, dorsal view, Epuraea subparallela, male holotype from Turkey, Nur Mts., above Akbez (= "Syria, Akbès", in the original label), MNHN. - k. Median lobe of aedeagus, dorsal view (same). - I. Paramera, lateral view (same). - m. Left antenna, E. subparallela, male holotype from Turkey, Nur Mts., MNHN. - n. Left antenna, E. rifensis, male paratype from Morocco, Rif, Bab-Besen, CAR. - o. Left antenna, E. latipes, male from Morocco, Rif, Bab-Besen, CAR. - p. Left antenna, Epuraea guttata, male from Italy, Tuscany, Florence, CAR. Scale bar $=0.4 \mathrm{~mm}$ (Figs. $3 a-1),=0.5 \mathrm{~mm}$ (Figs. $3 \mathrm{~m}-\mathrm{p}$ ). 
20.VII.-13.VIII.2010, S. S. Avgin leg., 28 specimens (CAR, NMPC, CAK, NMW, ARCC, CLB); $1 \hat{\partial}$, Turkey, Mersin province, road Erdemli to Güzeloluk, $25 \mathrm{~km}$ NE of Erdemli, $36^{\circ} 48^{\prime} \mathrm{N}, 34^{\circ} 10^{\prime} \mathrm{E}, 350 \mathrm{~m}$ a.s.1., 9-12.VI.2000, R. Królik leg. (NMPC); 1 ô 2 qq Turkey, Mersin province, $1.5 \mathrm{~km} \mathrm{~S}$ of Aydinlar, $1,395 \mathrm{~m}$ a.s.l., $36^{\circ} 45^{\prime} \mathrm{N}, 34^{\circ} 08^{\prime} \mathrm{E}, 20 . \mathrm{VII} .2004$, at light, R. Dobosz leg. (USMB); 23 $\hat{\delta} 17$ 우, ibidem, 31.VII.-2.VIII.2006, R. Dobosz leg. (USMB, CLB, RKK); 1 near Aydinlar, 9.-12.VI.2000, at light, R. Dobosz leg. (USMB); 1 $\hat{~} 1$, , ibidem, 19.VII.2004, R. Dobosz leg. (USMB); 7 \$๐ 6 q9 Turkey, Mersin province, Darıpınarı, $420 \mathrm{~m}$ a.s.1., $37^{\circ} 09^{\prime} \mathrm{N} / 34^{\circ} 44^{\prime} \mathrm{E}, 28$.-31.VII.2006, R. Dobosz leg. (USMB, CLB); $1 \hat{\jmath}$ Turkey, Isparta province, Yukangökdere near Eğridir, Kasnak Forest, 1,100-1,500 m a.s.l., 3742'58'N , 3049'54'”E, 19.VII.2007, window traps, N. Jansson \& M. Avci leg. (EMDI).

Additional material. Ten additional specimens collected at the type locality, preserved in pure acetone, awaiting molecular analyses.

Differential diagnosis. The new species is similar in external shape, color, and size (Fig. 1) to the closely related Epuraea latipes Grouvelle 1896 from western North Africa, which was redescribed by Audisio (1983, 1993). The species differs from $E$. latipes and other members of the species complex in the markedly longer and narrower paramera of the male genitalia (Figs. 3a-f) (see also the identification key below).

Description. 2.2-2.6 mm long (Fig. 1). Head, pronotum and elytra yellowish to light brown, discal area of elytra in some specimens slightly darker, reddish brown. Antennae and legs pale reddish brown. Almost identical to Epuraea latipes Grouvelle 1896 from western North Africa (Audisio 1983, 1993) in all other external characters. A detailed external description of the new species is then to be considered uninformative and unnecessary. See Audisio (1993, p. 322) for a recent and thorough description of $E$. latipes.

Male genitalia as figured (Figs 3d-f). Tegmen $1.80-1.85 \times$ longer than wide, with narrow paramera when observed in dorsal view (Fig. 3d), distinctly narrower and longer than in $E$. latipes, the latter exhibiting a tegmen only $1.50-1.55 \times$ longer than wide (Fig. 3a); tegmen scarcely curved distad in lateral view (Fig. 3f), less curved than in E. latipes (Fig. 3c).

Female ovipositor. Similar to that of E. latipes (see identification key below).

Distribution. Epuraea sutcuimamun sp. n., despite being presently known only from the few localities listed above, likely has a more widespread Taurian distribution, and probably occurs at least in the southern side of the Taurus and the Antitaurus Chain in southern Turkey, which coincides with the present-day distribution of cedar forests dominated by Cedrus libani A. Rich. (see discussion below).

Etymology. The specific epithet is a derivation of the Kahramanmaras Sutcu İmam University, Turkey, the species being dedicated to the Rector, Prof. Fatih Karaaslan, who kindly supported the entomological research of the first author in Turkey.

\section{Epuraea subparallela Grouvelle, 1896}

The type material of Epuraea subparallela Grouvelle was collected in southeast Turkey in a montane area above Osmaniye (Nur Mts., formerly known as Amanus Mts.: Grouvelle 1896) where relictual cedar forests occur (Audisio 1983, 1993, Hajar et al. 2010; see discussion below). The species was believed to be likely associated with cedars, despite recent (VI. 2002) trapping on Nur Mts. in a small cedar forest near the village of Yarpuz (Audisio unpublished data), which was unsuccessful in providing additional specimens. However, Epuraea material recently collected by N.J. in southern Turkey yielded a small series of specimens belonging to this taxon, as indicated below.

\subsection{Examined material}

1 d, 2 qq Turkey, Isparta province, Yukangökdere near Eğridir, Kasnak Forest, 1,100$1,500 \mathrm{~m}$ a.s.1., $37^{\circ} 42^{\prime} 58^{\prime \prime} \mathrm{N}, 30^{\circ} 49^{\prime} 54^{\prime \prime} \mathrm{E}, 17 . \mathrm{V}$. 2007, window traps, hollow Quercus, N. Jansson \& M. Avci leg. (CAR, EMDI, CJL); 1 q Turkey, Mersin province, $40 \mathrm{~km} \mathrm{~N}$ of Gülnar, Köseçobanli/Tasdüstü, $1,500 \mathrm{~m}$ a.s.l., 36³0' 
Fig. 4. - a. Paramera, dorsal view, Epuraea guttata, male from Italy, Tuscany, Florence, CAR. - b. Median lobe of aedeagus, dorsal view (same). - c. Paramera, lateral view (same). - d. Paramera, dorsal view, Epuraea fuscicollis male from Italy, Latium, Circeo National Park. - e. Median lobe of aedeagus, dorsal view (same). $-f$. Paramera, lateral view (same). - g. Metatibia, dorsal view, E. guttata, male from Italy, Tuscany, Florence, CAR. - h. Metatibia, dorsal view, E. guttata, female from Italy, Tuscany, Florence, CAR. - i. Metatibia, dorsal view, E. fuscicollis, male from Italy, Latium, Circeo National Park, CAR. Scale bar $=0.4 \mathrm{~mm}$.
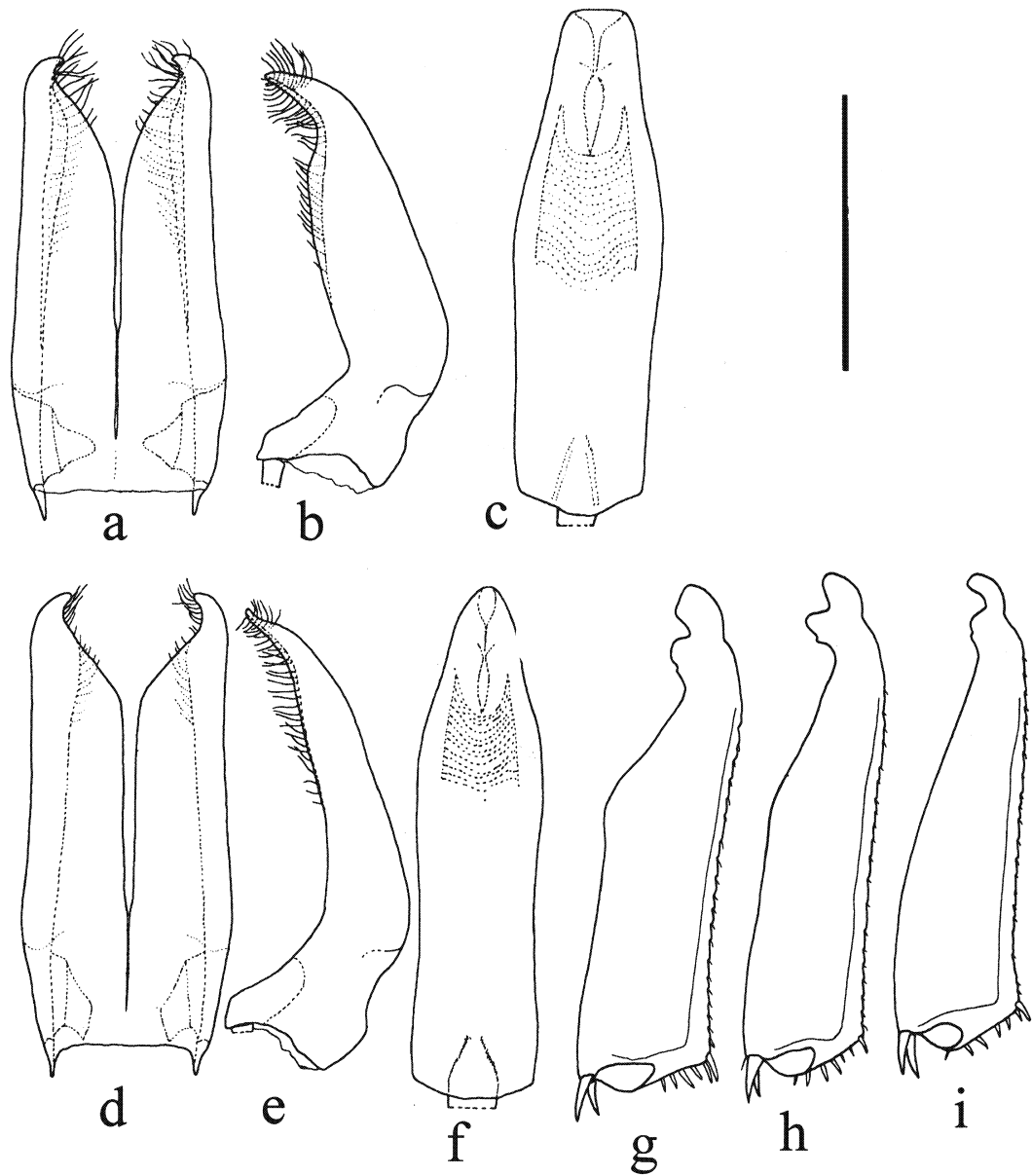

22'N, 3307'43”E, 24.V.2006, window traps, hollow Quercus, N. Jansson \& M. Coskun leg. (ARCC); 1 i ibidem, 26.VII.2006 (CAR); 1 \% ibidem, 26.VIII.2006 (EMDI).

\subsection{Variation}

The species was previously known from two specimens, the single male holotype (MHNP) and one additional female probably from the same original locality (CAR; see Audisio 1983). The currently available small series from southern Turkey enables a greater appreciation of the rather unusual variation in size (body length: 2.8 $4.5 \mathrm{~mm}$ ) and general body shape of the species includes a variable proportion between elytral length and elytral width (ratio elytral length/elytral width $=1.18-1.25)$.

\subsection{Ecological data}

Specimens of the recently collected series were obtained using flight intercept window traps positioned on a tree trunk, surrounded by hollow oak trees (Quercus spp.), in a largely grazed area that is being heavily transformed by local farmers (Köseçobanli/Tasdüstü; oak species where the window traps were mounted: Quercus ithaburensis Decaisne, 1835, and Q. cerris Linnaeus, 1753). Other recently collected specimens were obtained from a nature reserve with free growing oaks in a grazed environment with several oaks in a more forested condition (Kasnak Forest; oak species where the window traps were mounted: Quercus libani G.Olivier, 1801 and $Q$. x szechenyana Borbas, 1886 (=Q. vulcanica Borzi, 1805 [hybrid between $Q$. pubescens Willd. and $Q$. frainetto Ten.]), in a mixture of other tree species 


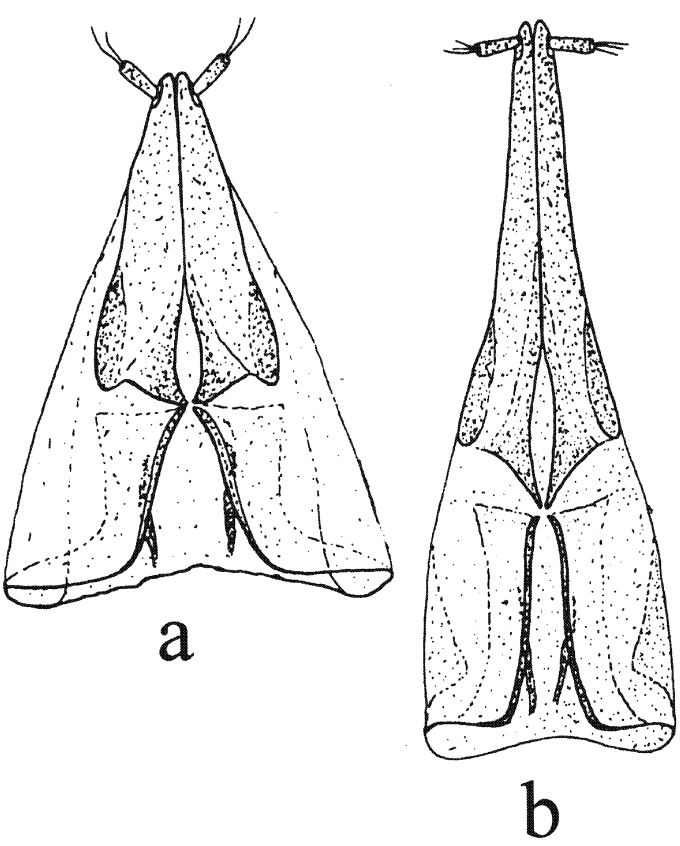

like Cedrus libani A. Rich., Pinus spp., Juniperus spp., Acer spp., and Fraxinus spp.

\section{Identification key to species of Dadopora lineage}

1. Elytra broadly and separately rounded distad (Figs. 1, 2a-b).

- Elytra broadly truncate distad (Figs. 2c-d). 5

2. Antennae markedly shorter, $0.75-0.80 \times$ as long as head width (Figs. 1, 2b), with antennomere 5 nearly as long as wide (Fig. 3o). Space between mesocoxal cavities only slightly narrower than space between procoxal cavities. Dorsal surface uniformly ochreous, reddish or testaceous, without lighter yellowish spots on elytra and pronotum (Fig. 1) well-defined. On average, body smaller (length: 2.0-3.0 mm) and slender (Figs. 1, 2b). Male genitalia as in Figs. 3a-f. 3

- Antennae markedly longer, $0.90-0.95 \times$ as long as head width (Fig. 2a), chiefly with antennomere 5 much longer than wide (Fig. $3 p)$. Space between mesocoxal cavities more distinctly narrower than space between procoxal cavities. Dorsal surface typically

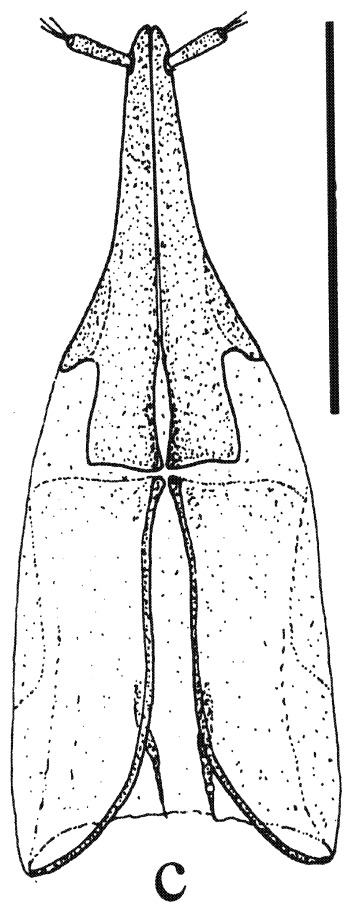

Fig. 5. - a. Ovipositor, ventral view, Epuraea latipes, female from Morocco, Rif, BabBesen, CAR. - b. Ovipositor, ventral view, Epuraea rifensis, female paratype from Morocco, Rif, BabBesen, CAR. - c. Ovipositor, ventral view, Epuraea subparallela, female from Turkey, Nur Mts., CAR. Scale bar $=0.3 \mathrm{~mm}$.

nut-brown to pale brown, with several lighter yellowish spots on elytra and pronotum (Fig. 2a) rarely well-defined. On average, body larger (length: 2.2-4.4 mm) and wider (Fig. 2a). Male genitalia as in Figs. 4a-f.

3. Male genitalia short, tegmen 1.50-1.55× longer than wide, paramera wider in dorsal view and more curved distad in lateral view (Figs. 3a-c). Western North Africa (Morocco, N Algeria). Epuraea latipes Grouvelle, 1896

- Male genitalia long, tegmen 1.80-1.85× longer than wide, paramera narrower and thinner in dorsal view and less curved distad in lateral view (Figs. 3d-f). Southern Turkey (Taurus Chain).

Epuraea sutcuimamun sp.n.

4. Inner margin of male metatibiae with prominent obtuse projection at proximal third (Fig. $4 \mathrm{~g}$ ), less prominent but distinct in females (Fig. 4h). Male genitalia as in Figs. 4a-c. Europe, Caucasus.

Epuraea guttata (Olivier, 1811)

- Inner margin of metatibiae simple in both sexes (Fig. 4i). Male genitalia as in Figs. 4d-f. Europe, Caucasus, N Iran, North Africa. Epuraea fuscicollis (Stephens, 1832)

5. Third joint of antennal club smaller than second (Fig. 3n). Body relatively oval and 


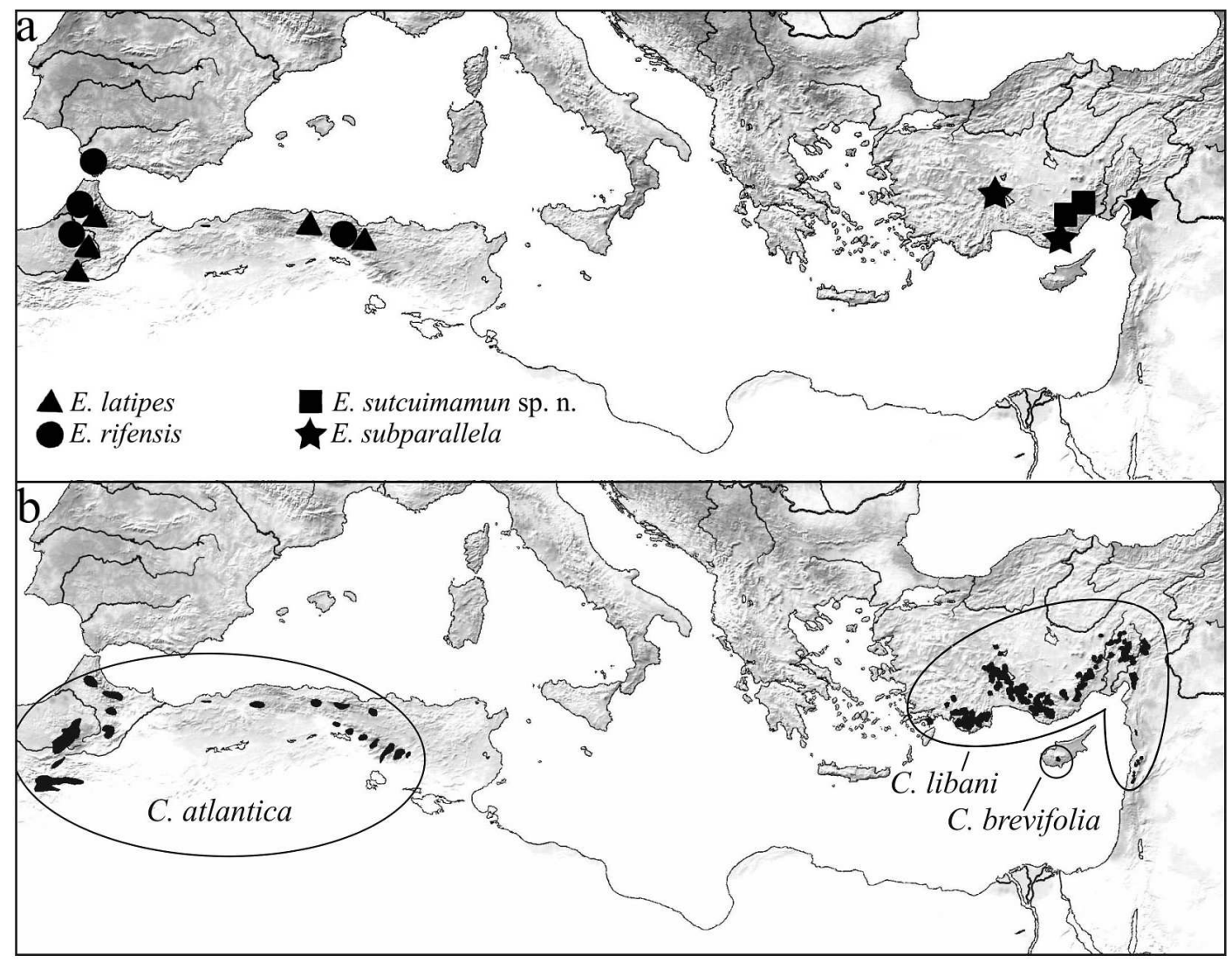

Fig. 6. - a. Distribution map of Epuraea spp. of the E. latipes group. - b. Distribution map of Cedrus spp. in the Mediterranean areas of Morocco and Algeria, Cyprus, as well as Turkey, Syria and Lebanon (redrawn from Quézel 1980, Hajar et al. 2010).

smaller, with shorter elytra (body length: $2.5-$ $3.3 \mathrm{~mm}$ ). Habitus as in Fig. 2c. Male genitalia as in Figs. 3g-i. Ovipositor as in Fig. 5b. Western North Africa (Morocco, N Algeria) and S Spain. Epuraea rifensis Audisio, 1983

- Third joint of antennal club nearly as large as preceding two combined (Fig. 3m). Body more parallel-sided, larger (body length: $2.8-$ $4.5 \mathrm{~mm}$ ). Habitus as in Fig. 2d. Male genitalia as in Figs. 3j-1. Ovipositor as in Fig. 5c. S Turkey.

Epuraea subparallela Grouvelle, 1896

\section{Discussion}

As discussed by Peyerimhoff (1926), Epuraea latipes Grouvelle from western North Africa is strictly associated in northern Algeria with oldgrowth cedar forests (Cedrus atlantica (Endl.)
Manetti ex Carrière; Pinaceae). There this species is a specialized saproxylic element on the phytoparasitic fungus Clavaria cedretorum R. Maire (Fungi, Clavariaceae), which grows on rotting cedar trees (Peyerimhoff 1926, Méquignon 1945). The same ecology is shared in North Africa (Morocco and Algeria) by the frequently sympatric E. rifensis Audisio. However, in extreme southern Spain (i.e. mountainous areas of the Cadiz province) this species was surprisingly collected in forests dominated by xerophilous oaks in areas where cedars are now absent (Audisio 1983, 1993 and unpublished data; Figs. 6a-b). Epuraea subparallela Grouvelle, was collected in southeastern Turkey in a montane area above Osmaniye (Nur Mts., formerly known as Amanus Mts.). Relictual cedar forests occur there (Audisio 1983, 1993, Hajar et al. 2010; Figs. 6ab), and the species was believed to be probably associated with cedars. A recent (VI/2002) un- 

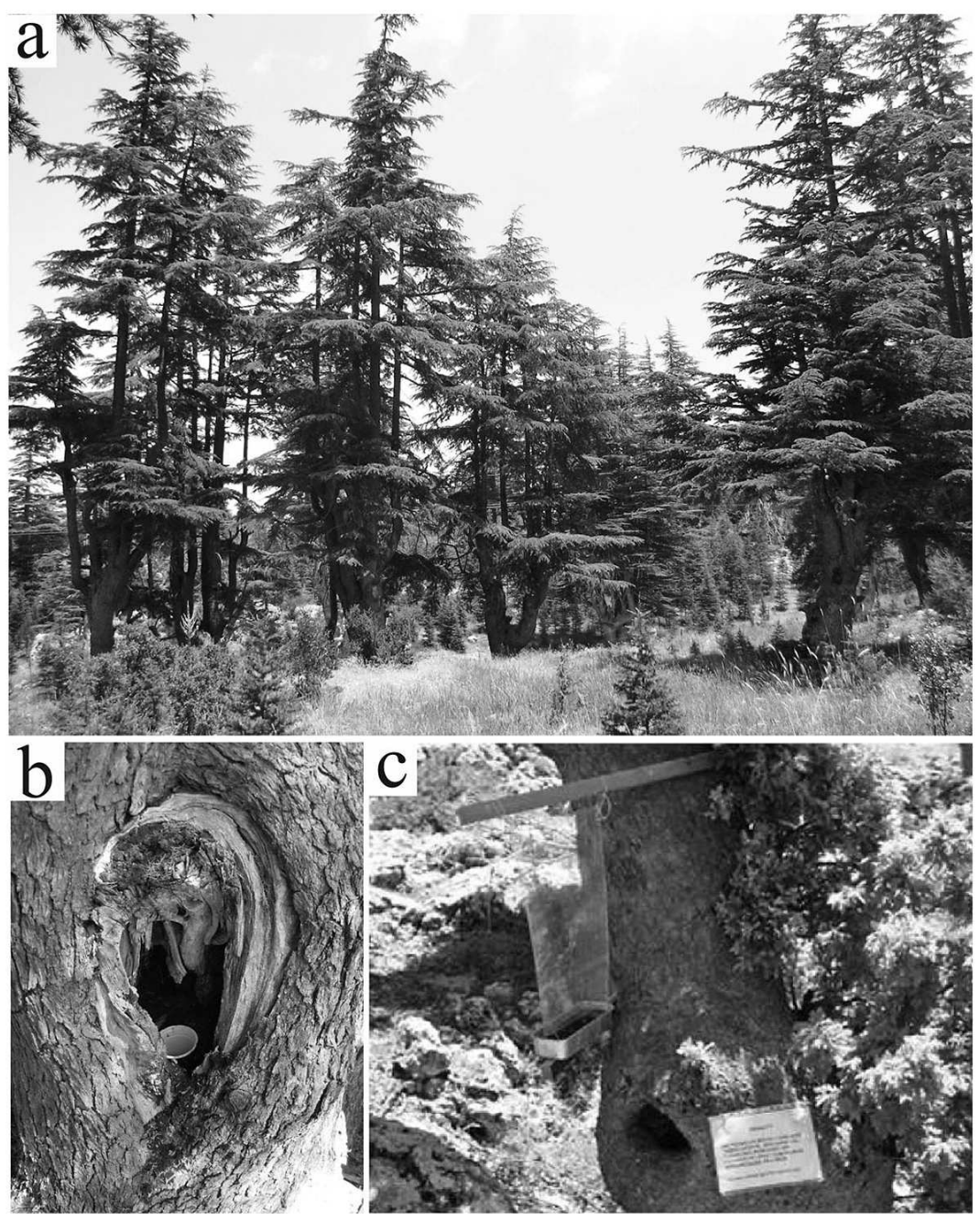

Fig. 7. - a. The Kargagedigi old-growth cedar forest, near Aydinlar village, Turkey, type locality of Epuraea sutcuimamun sp. n. (photo: P. Audisio). - b. Hollow tree with a pitfall trap at the same locality (photo: S. S. Avgin). -c. Window trap in an hollow oak (Quercus cerris) in southern Turkey (photo: N. Jansson).

successful collecting event in cedar forests on Nur Mts near the village of Yarpuz (Audisio, unpublished data), and the above cited new records on hollow oaks in Isparta and Mersin provinces, clearly suggest its actual association with oak forests. The relationships of most members of the Epuraea latipes species group with cedars appears rather strict, suggesting parallel biogeographic tracks between these specialized sap beetles, the clavariaceae fungus, and cedar trees throughout the Mediterranean region (Fig. 6). However, as reported above, the $E$. latipes group is closely related to both recognized members of the Dadopora lineage, i.e. E. fuscicollis (Stephens, 1832) and E. guttata (Olivier, 1811) from central and southern Europe and the Near East. "Dadopora" members are saproxylic elements strictly associated with fermenting sap produced by oaks following attacks by xylophagous insect larvae (Ratti 1978, Audisio 1993), and frequently inhabit old-growth forests and hollow trees (Figs. $7 \mathrm{a}-\mathrm{c})$.

Cedrus (true cedar) comprises four species with a highly disjunct distribution in circumMediterranean (Fig. 6b) and western Himalayas regions, i.e. Cedrus deodara (Roxb.) G. Don in the Hindu Kush, Karakorum and Indian Himalayan areas, Cedrus libani A. Rich in Turkey, Lebanon and Syria, Cedrus brevifolia (Hook. f.) Henry in Cyprus, and Cedrus atlantica (Endl.) Manetti ex Carrière in North Africa (northern Algeria and Morocco) (Quézel 1980, Qiao et al. 2007). Combined molecular, palaeogeographical and palaeoecological studies indicate that Cedrus 
could have originated in the high latitude areas of Eurasia in the Paleogene, and its present distribution may be due to vicariance of southerly migrated populations during the Neogene, with further fragmentation and dispersal of these populations during Quaternary climatic oscillations (Qiao et al. 2007, Dagher-Kharrat et al. 2007).

Fossil data indicate that during the Middle Miocene (16-11 Ma) Cedrus was present in Turkey (Yavuz-Işık 2007), Bulgaria (Ivanov et al. 2002), and Austria (Jiménez-Moreno et al. 2008). During the Messinian (7.2-5.3 Ma), Cedrus was present in the Italian peninsula (Bertini \& Martinetto 2011), where it persisted until the end of the early Pleistocene (ca. 0.8 Ma) and possibly later (Corrado \& Magri 2011). In the Pliocene (5.3-2.6 Ma), Cedrus was found in southern France (Fauquette et al. 1999) and northern Spain (Suc \& Cravatte 1982). By the Early Pleistocene it was not locally present in southern France (2 Ma: Leroy \& Roiron 1996) or northern Spain (ca. 1.5 Ma: Leroy 1997) any longer. In continental Iberian pollen records south of $41^{\circ} \mathrm{N}$ latitude, only discontinuous occurrences of Cedrus pollen are documented from the Miocene to Pleistocene (Jiménez-Moreno \& Suc 2007, Barrón et al. 2010). Similar sporadic occurrences, due to longdistance pollen transportation, appear in Holocene records from central Mediterranean regions (Magri \& Parra 2002). Although Postigo-Mijarra et al. (2010) suggest that Cedrus may have been present in the Iberian peninsula during the Quaternary, continuous and appreciable records (2$6 \%$ ) of Cedrus pollen are documented only from Upper Paleolithic-Epipaleolithic sediments (34$7 \mathrm{ka}$ BP) in a coastal cave near Malaga (CortésSánchez et al. 2008). These finds indicate a recent occurrence of Cedrus in the southernmost areas of Spain.

Only sparse fossil data are available from North Africa. However, regular occurrences of Cedrus pollen are recorded in Messinian sediments from western Morocco, suggesting that cedar was present in the Middle Atlas mountains (Feddi et al. 2011). A few cores from the Alboran Sea, which should be considered with a caution due to the over-representation of Cedrus in marine sediments, indicate its persistence during the Pliocene and Pleistocene (Feddi et al. 2011, Joannin et al. 2011). A marine core from the Me- diterranean Sea off the coast of Libya spanning the last $245 \mathrm{ka}$ does not record Cedrus pollen (Cheddadi 1988). Therefore, the fossil data suggest that Cedrus did not expand into the Iberian Peninsula south of $41^{\circ} \mathrm{N}$, except along restricted coastal areas of southern Spain during the last glacial period. The cedar populations presently occurring in Morocco most likely descend from Upper Miocene populations that persisted in North Africa. By contrast, the European populations progressively disappeared during the early and middle Pleistocene (Tzedakis et al. 2006, Corrado \& Magri 2011).

We hypothesize from preliminary results of morphological phylogenetic studies on Holarctic Epuraeainae (Audisio, unpublished data) that the current species of the $E$. latipes clade originated from an ancestral Epuraea species previously associated with boreal coniferous forests, most likely related to the present-day eastern Siberian Epuraea quadrangula Motschulsky, 1860. This ancestor then shifted to Cedrus during the first appearance of their present-day Mediterranean location ( $20-15 \mathrm{Ma}$ ago), following a much older separation of the Himalayan Cedrus deodara from the lineage including the three Mediterranean species (Qiao et al. 2007). Along the same ancestral stem, another early cladogenetic event likely occurred, probably during the EarlyMiddle Miocene in Near East, in concurrence with an early shift onto oaks, involving the origin of E. subparallela (the morphologically more isolated species of the E. latipes group) and the common ancestor of both E. guttata and $E$. fuscicollis. In a sister clade including the strictly cedar-associated species, Epuraea rifensis could be interpreted as the product of a more ancient range expansion of cedars and associated saproxylic beetle communities within North Africa, and further expanded its range with the subsequent local speciation of Cedrus atlantica $(\sim 18$ $10 \mathrm{Ma}$ ) (Qiao et al. 2007).

The present-day occurrence of E. rifensis in southern Spain would be more parsimoniously attributed to a diffusion of both beetles and cedars onto the Iberian Peninsula prior to the reopening of the Gibraltar Strait at the end of the Messinian salinity crisis ( $\sim 5 \mathrm{Ma})$. However, this scenario is not supported by palynological data, which suggests absence of cedars in southern Spain (Barrón 
et al. 2010) and the northwestern coast of Morocco (Feddi et al. 2011) during the Messinian. At that time Cedrus was known from the Rabat area in central-western Morocco (Feddi et al. 2011). However, cedars may have marginally reached Spain via the Gibraltar Strait from northern Morocco during one of the last glacial periods at a time with markedly lower sea levels, thereby allowing a limited Würmian presence of $C$. atlantica in extreme southern Spain (CortésSánchez et al. 2008, Terrab et al. 2008). The presence of coastal cedar forests in northern Morocco and northern Algeria during the last glacial maximum has been demonstrated (Cheddadi et al. 2009), and was followed by postglacial local extinction of low altitude cedar populations. The present-day occurrence of E. rifensis in xerophilous oak forests of southern Spain may then be interpreted as an extreme "ecological relict" of this limited Würmian presence of C. atlantica forests along the southern coast of the Iberian Peninsula.

Similar patterns of relatively long term survival of Epuraea populations that are strictly associated with coniferous trees in modern day deciduous tree forests have been documented. In the Palaearctic, Epuraea marseuli Reitter 1872, which is typically associated with Pinus, Abies and Picea forests, is also known to occur in relictual pockets in northern Sicily at the edge of Fagus and Quercus forests where previous Holocene populations of Abies have been documented (Audisio et al. 1985).

Finally, the common ancestor of E. sutcuimamun sp. n. and E. latipes likely originated in the Near East on Cedrus libani, and expanded to North Africa during the Pleistocene at a time with markedly lower sea levels. This event possibly followed a documented presence of cedar forests in the Balkan and Italian peninsulas and Sicily, where Cedrus was present until at least the Early/Middle Pleistocene ( $\sim 0.8 \mathrm{Ma})$. Fossil data indicate the absence of Cedrus in northeastern Africa, including northern Libya and northern Egypt, during the Middle and Late Pleistocene (Cheddadi 1988) at a time when sporadic pollen grains are apparent in the Italian records (Magri \& Parra 2002). Under this scenario, E. latipes is likely a more recent and only moderately differentiated Maghrebinian element of a widespread eastern Mediterranean species, associated with Cedrus libani, that migrated west and southward during an Early/Middle Pleistocene glacial period, eventually reaching North African $C$. atlantica forests, whose range had been recently fragmented (Cheddadi et al. 2009).

Molecular data are currently unavailable for many Epuraea species from both northern African species and E. subparallela. Further field research in Morocco, southern Spain, and in the recently discovered new localities in southern Turkey is planned to provide fresh specimens for molecular sequencing. These molecular data will test the palaeoecological and evolutionary hypothesis introduced herein for the entire clade. One component of the molecular analyses will be to investigate isolated, and relict populations (like those discovered in southern Spain) of Epuraea of the latipes clade potentially occurring on the Italian and Hellenic peninsulae, where, as discussed above, relatively large forests of Cedrus species were present before their Middle Pleistocene decline.

Acknowledgements. This paper was supported by M.I.U.R. - "Sapienza, University of Rome $60 \%$ funds" (Grant 2006 "Aspetti genetici e morfometrici della biodiversità animale in aree africane e medio-orientali a basso impatto antropico"), and by Centro Nazionale per la Biodiversità Forestale, Verona, Italy (grant 2009 "Monitoraggio e conservazione della biodiversità degli invertebrati saproxilici"). We thank our Polish and Turkish colleagues and friends who contributed to the collection of sap beetles in southern Turkey and to Roland Dobosz (USMB) and Roman Królik (RKK) for lending us material in their care. We also thank J. Jelínek (Praha, Czech Republic) for reviewing a previous version of the manuscript and offering his insights and knowledge on this diverse genus of beetle. We are indebted to Dr. Pierfilippo Cerretti (CNBF, Verona, Italy) for photographs of the new species. We gratefully thank Mr. Selim Avgin, father of the first author, for his help in collecting specimens of the new species, and Erdoğan Üstüner, Volkan Demir and other foresters at the Forest Management Directorate in Erdemli, Mersin, Turkey, for their kind logistic assistance. Finally, we gratefully thank Prof. Mustafa Avci (Forest Faculty, Demirel University, Isparta, Turkey), Mustafa Coskun and Dr. Tamer Kayis (Department of Biology, Adiyaman University, Adiyaman, Turkey), for their kind logistic and scientific assistance during the N.S. studies on saproxylic insect communities in southern Turkey. 


\section{References}

Audisio, P. 1983: Tassonomia e distribuzione geografica di Epuraea latipes Grouvelle e specie correlate (Coleoptera, Nitidulidae). - Fragmenta Entomologica 17: $111-123$.

Audisio, P. 1993: Coleoptera Nitidulidae - Kateretidae. Fauna d'Italia. - Calderini, Bologna. 971 pp.

Audisio, P., Biondi, M. \& Bologna, M. A. 1985: Studio di entomocenosi a Coleotteri fitofagi dell'Appennino Siculo orientale. - Atti XIV Congresso Nazionale Italiano di Entomologia, Palermo, Erice, Bagheria: 57-64. [In Italian]

Barrón, E., Rivas-Carballo, R., Postigo-Mijarra, J. M., Alcalde-Olivares, C., Vieira, M., Castro, L., Pais, J. \& Valle-Hernández, M. 2010: The Cenozoic vegetation of the Iberian Peninsula: a synthesis. - Review of Palaeobotany and Palynology 162: 382-402.

Bertini, A. \& Martinetto, E. 2011: Reconstruction of vegetation transects for the Messinian-Piacenzian of Italy by means of comparative analysis of pollen, leaf and carpological records. - Palaeogeography, Palaeoclimatology, Palaeoecology 304: 230-246.

Brandmayr, P., Zetto, T., \& Pizzolotto, R. 2005: I Coleotteri Carabidi per la valutazione ambientale e la conservazione della biodiversità. Manuale operativo. A.P.A.T. Manuali e Linee Guida. 240 pp. [In Italian]

Cheddadi, R. 1988: Paléoclimats au nord de la Méditerranée orientale dépuis 250000 ans. Analyse pollinique et stratigraphie isotopique de quatre carottes marines. $\mathrm{PhD}$ thesis, Université des Sciences et Techniques du Languedoc, Montpellier.

Cheddadi, R., Fady, B., François, L., Hajar, L., Suc, J. P., Huang, K., Demarteau, M., Vendramin, G. G. \& Ortu, E. 2009: Putative glacial refugia of Cedrus atlantica deduced from Quaternary pollen records and modern genetic diversity. - Journal of Biogeography 36 : 1361-1371.

Corrado, P. \& Magri, D. 2011: A late Early Pleistocene pollen record from Fontana Ranuccio (central Italy). - Journal of Quaternary Science 26: 335-344.

Cortés-Sánchez, M., Morales-Muñiz, A., Simón-Vallejo, M. D., Bergadà-Zapata, M. M., Delgado-Huertas, A., López-García, P., López-Sáez, J. A., Lozano-Francisco, M. C., Riquelme-Cantal, J. A., Roselló-Izquierdo, E., Sánchez-Marco, A. \& Vera-Peláez, J. L. 2008: Palaeoenvironmental and cultural dynamics of the coast of Málaga (Andalusia, Spain) during the Upper Pleistocene and early Holocene. - Quaternary Science Reviews 27: 2176-2193.

Dagher-Kharrat, M. B., Mariette, S., Lefèvre, F., Fady, B., Grenier-de March, G., Plomion, C. \& Savouré, A. 2007: Geographical diversity and genetic relationships among Cedrus species estimated by AFLP. Tree Genetics \& Genomes 3: 275-285.

Fauquette, S., Clauzon, G., Suc, J. P. \& Zheng, Z. 1999: New approach for palaeoaltitude estimates based on pollen records: example of the Mercantour Massif (southeastern France) at the earliest Pliocene. - Earth and Planetary Science Letters 170: 35-47.
Feddi, N., Fauquette, S. \& Suc, J. P. 2011: Histoire pliopléistocène des écosystèmes végétaux de Méditerranée sud-occidentale: apport de l'analyse pollinique de deux sondages en mer d'Alboran. - Geobios 44: 57 69.

Grouvelle, A. 1896: Deux nouvelles espéces d'Epuraea (Col.) du bassin méditerranéen. - Bulletin de la Societé Entomologique de France 1896: 278-279.

Grouvelle, A. 1913 : Byturidae, Nitidulidae pars 56. In: Junk W. \& Schenkling S. (eds.), Coleopterorum Catalogus: 1-223. Berlin.

Hajar, L., François, L., Khater, C., Jomaa, I., Déqué, M. \& Cheddadi, R. 2010: Cedrus libani (A. Rich) distribution in Lebanon: Past, present and future. - Comptes Rendus Biologies 333: 622-630.

Ivanov, D., Ashraf, A. R., Mosbrugger, V. \& Palamarev, E. 2002: Palynological evidence for Miocene climate change in the Forecarpathian Basin (Central Paratethys, NW Bulgaria). - Palaeogeography, Palaeoclimatology, Palaeoecology 178: 19-37.

Jansson, N. \& Coskun, M. 2008: How similar is the saproxylic beetle fauna on old oaks (Quercus spp.) in Turkey and Sweden? — Revue d'Écologie (Terre Vie) 63: 83-91.

Jelínek, J. \& Audisio, P. 2007: Family Nitidulidae. - In: Löbl, I. \& Smetana, A. (eds.), Catalogue of Palaearctic Coleoptera. Vol. 4: Elateroidea-Derodontoidea-Bostrichoidea - Lymexyloidea - Cleroidea - Cucujoidea: 459-491. - Apollo Books, Stenstrup, 935 pp.

Jiménez-Moreno, G. \& Suc, J. P. 2007: Middle Miocene latitudinal climatic gradient in Western Europe: evidence from pollen records. - Palaeogeography, Palaeoclimatology, Palaeoecology 253: 208-225.

Jiménez-Moreno, G., Fauquette, S. \& Suc, J. P. 2008: Vegetation, climate and palaeoaltitude reconstructions of the Eastern Alps during the Miocene based on pollen records from Austria, Central Europe. - Journal of Biogeography 35: 1638-1649.

Joannin, S., Bassinot, F., Combourieu Nebout, N., Peyron, O. \& Beaudouin, C. 2011: Vegetation response to obliquity and precession forcing during the Mid-Pleistocene Transition in Western Mediterranean region (ODP site 976). - Quaternary Science Reviews 30: $280-297$.

Kirejtshuk, A. G. 1998: Nitidulidae (Coleoptera) of the Himalayas and northern Indochina. Part 1: Subfamily Epuraeinae. - Koeltz Scientific Books, Koenigstein, Germany. 489 pp.

Koivula, M., Kotze, D. J., Hiisivuori, L. \& Rita, H. 2003: Pitfall trap efficiency: do trap size, collecting fluid and vegetation structure matter? - Entomologica Fennica 14: $1-14$.

Lason, A. 2007: A contribution to the knowledge of the sap beetles of Turkey (Coleoptera: Nitidulidae and Kateretidae). - Annals of the Upper Silesian Museum (Entomology) 14-15: 195-221.

Lemieux, J. P. \& Lindgren, B. S. 1999: A pitfall trap for large-scale trapping of Carabidae: comparison against conventional design, using two different preservatives. - Pedobiologia 43: 245-253. 
Leroy, S. 1997: Climatic versus non climatic lake-level changes from a Plio-Pleistocene lacustrine complex of Catalonia (Spain): palynology of the Tres Pins sequences. - Journal of Paleolimnology 17: 347-367.

Leroy, S. \& Roiron, P. 1996: Final Pliocene pollen and leaf floras from Bernasso palaeolake (Escandorgue Massif, Hérault, France). - Review of Palaeobotany and Palynology 94: 295-328.

Magri, D. \& Parra, I. 2002: Late Quaternary western Mediterranean pollen records and African winds. - Earth and Planetary Science Letters 200: 401-408.

Méquignon, A. 1945: Sur quelques types d'Epuraea conservés au Museum dc Paris (Col. Nitidul idae). - Revue Française d'Entomologie 12: 14-21.

Niemelä, J. 1998: Proposed standardised trapping design. Symposium "Global biodiversity and its monitoring: focus on insects", Helsinki 20 April 1998. - Internet: http://www.helsinki.fi/science/globenet/std.html (last accession: March, 2012).

Peyerimhoff, F. 1926: Notes sur la biologie de quelques Coléoptéres phytophages du Nord Africain (quatriéme série) avec les descriptions de quatre espéces nouvelles et de quatre sous-espéces. - Annales de la Societé Entomologique de France 95: 310-390.

Postigo-Mijarra, J. M., Morla, C., Barrón, E., MoralesMolino, C. \& García, S. 2010: Patterns of extinction and persistence of Arctotertiary flora in Iberia during the Quaternary. - Review of Palaeobotany and Palynology 162: 416-426.

Qiao, C. Y., Ran. J. H., Li. Y. \& Wang, X. Q. 2007: Phylogeny and biogeography of Cedrus (Pinaceae) inferred from sequences of seven paternal chloroplast and maternal mitochondrial DNA regions. - Annals of Botany $100: 573-580$.

Quézel, P. 1980: Biogéographie et écologie des conifers sur le poutour mèditerranéen. In: Pesson M. (ed.), Ac- tualités d'écologie forestière: 205-255. — GauthierVillars, Paris.

Ratti, E. 1978: La coleotterofauna delle ferite di Quercus robur L. nelle Prealpi Varesine. - Atti del Convegno di Ecologia delle Prealpi Orientali. - «Gruppo Gadio», Pian Cansiglio, 6-8 maggio 1978: 295-325. [In Italian]

Reitter, E. 1919: Bestimmungs-Tabelle der europäischen Coleopteren. Heft 86. Nitidulidae und Byturidae. Verhandlungen der Naturforschenden Vereins in Brünn 50: 1-104.

Sjöberg, O. 1939: Beitrag zur Kenntnis der Gattung Epuraea Er. (Col. Nitidulidae). Bestimmungstabelle der paläarktischen Arten. - Entomologische Tijdskrift 60: $108-126$

Suc, J. P. \& Cravatte, J. P. 1982: Étude palynologique du Pliocène de Catalogne (nord-est de l'Espagne). - Paléobiologie Continentale. 13: 1-31.

Terrab, A., Hampe, A., Lepais, O., Talavera, S., Vela, E. \& Stuessy, T. F. 2008: Phylogeography of north african atlas cedar (Cedrus atlantica, Pinaceae): combined molecular and fossil data reveal a complex quaternary history. - American Journal of Botany 95: 12621269.

Tzedakis, P. C., Hooghiemstra, H. \& Pälike, H. 2006: The last 1.35 million years at Tenaghi Philippon: revised chronostratigraphy and long-term vegetation trends. - Quaternary Science Reviews 25: 3416-3430.

Yavuz-Iş1k, N. 2007: Pollen analysis of coal-bearing Miocene sedimentary rocks from the Seyitömer Basin (Kütahya), Western Anatolia. - Geobios 40: 701708.

Waage, B. E. 1985: Trapping efficiency of carabid beetles in glass and plastic pitfall traps containing different solutions. - Fauna Norvegica Series B 32: 33-36. 